\title{
4 \\ To Rehabilitate and Return a Bishop in Flight
}

Having thoroughly investigated every form of slander and wickedness and having discovered that all <their efforts $>$ were being overcome by the truth, they sought refuge in the illegal laws of the Arians and with them plotted evil concerning the saint [John], copying < the Arians'> madness concerning the blessed Athanasius [concerning his return].

-PS.-MARTYRIUS, FUNERARY SPEECH FOR JOHN CHRYSOSTOM ${ }^{1}$

The forty bishops who held communion with Arius had legislated that "if any bishop or any priest who had been deposed, justly or unjustly, should reenter his church on his own initiative, without permission of a synod, such a one shall have no opportunity of defense, but shall be absolutely excluded." Now that canon was declared null and void as being illegal and passed by illegal persons....

-PAlladius, Dialogue on the life of JOHN CHRYSOSTOM ${ }^{2}$

As we have come to see throughout this book, the reputation of a bishop was often determined and solidified in the works of his defenders. But whose message should we trust? Is it that of the naysayers, who condemn any man in flight? As Tertullian had remarked, a man who flees persecution is clearly at fault. Or is it the word of those who properly reorder and orient our understanding of the events surrounding an orthodox flight the more trustworthy of voices? A temporary exile could be explained away as long as the man in flight returned triumphant. And yet some exiles never return. What are we to make of the man suspended in flight?

1. Ps.-Martyrius, Fun. Orat. 99. Edition: M. Wallraff (ed.) and C. Ricci (trans.), Ps.-Martyrius, Oratio funebris in laudem sancti Iohannis Chrysostomi: epitaffio attribuito a Martirio di Antiochia (BHG 871, CPG 6517), Quaderni della Rivista di bizantinistica 12 (Spoleto: Fondazione Centro italiano di studi sull'Alto Medioevo, 2007). Translation: T. D. Barnes and George Bevan, The Funerary Speech for John Chrysostom, Translated Texts for Historians 60 (Liverpool: Liverpool University Press, 2013), with slight alterations for clarity marked here by brackets, unless otherwise noted.

2. Palladius, Dia. 9. Edition: SC 341-42. Translations mine. 
We are left to conclude that the memory-making exercise and its intersection with exilic discourse was a fraught process, particularly when the very terms of exile appeared to shift, as we saw in John Chrysostom's reflections on his status as an exile in the previous chapter. John, that failed bishop of Constantinople, did not return triumphant. His defenders, who sought to recover John's reputation, and whose work we will explore in this chapter, were left with a new and difficult challenge: how do they recover the reputation of their hero when his death appeared to confirm his guilt? Even John's finals words on the subject of exile threatened to undermine his earlier, and more defensible, thoughts on the subject.

As we explored, John Chrysostom's exilic discourse transitioned from a local to a universal one as it became clear that he would not return triumphant but would die a condemned man. It is rare to find biographies, ancient or contemporary, that emphasize this point. Instead, John's biographers continued to proclaim him as a defender of the faith and an unquestionably orthodox father of the church. They did not ignore his exile, but they did make clear that John died a victim of circumstance and assured their readers that he was not a heretic. We have an unusual abundance of evidence regarding the circumstances of John's expulsion from Constantinople, yet the details contained in both his own account and the accounts offered by his biographers provoke more questions than they answer. ${ }^{3}$ Again, we must ask: whose word should we trust? If words fail, John's biographers argue, then the spaces of orthodoxy must prove the innocence of the man in flight.

In this chapter, I will show how two ancient biographers, the so-called Ps.Martyrius and Palladius of Helenopolis, offer significantly altered versions of the events leading up to and during John's exile from Constantinople. His defenders did not invoke their hero's final vision of a universalized exile but instead drew their readers back to the space he was first exiled from. They made Constantinople once again a central focus for the promotion and restoration of John's afterlife, much as Gregory of Nazianzus did with Athanasius's legacy. According to John's biographers, it is clear that the reasons for his exile were tied directly to his status as a symbol of Christian truth in a theologically infused space. For Ps.-Martyrius and Palladius, what was at stake in how they told the story was not just John's legacy but also the legacy of Constantinople and its orthodoxy. And it is their version of the events that influenced how later pro-Nicene authors would remember John and his two exiles.

To accomplish this goal, we will concern ourselves with how both of John's biographers localize his exile as they begin to sort out the heretics from the orthodox. As many scholars have noted, John was not only embroiled in the Trinitarian controversies surrounding Arianism, but he also found himself similarly intertwined with the growing Origenist controversies of the later fourth and early fifth 
centuries. ${ }^{4}$ His reputation as a bishop became the intense focus of a Johanite faction in and around Constantinople soon after his death. John's orthodoxy was called into question precisely because he died while in exile. Finally, we conclude with an examination of how John's memory was revived and returned to the recognizably orthodox space of Constantinople.

As we will see, John must be returned to that glowing city of Nicene orthodoxy. Yet, as the two epitaphs that open this chapter point out, the return was as challenging to retell as the removal itself. John's posthumous return must therefore be tied to another return, and the biographers accomplish this by invoking the legacy of Athanasius, bringing it into the city of Constantinople, even if by seemingly conflicting routes. John Chrysostom and Athanasius of Alexandria both embody a complex history of Christian flight that must be reconciled within the boundaries of Constantine's, and later Theodosius's, city of Christian orthodoxy.

\section{HOW TO DIAGNOSE EXILE: PS.-MARTYRIUS'S FUNERARY SPEECH}

The lesser-known Ps.-Martyrius provides yet another example of how Christian flight and heresiological discourse travel within the orthodox project. In his Funerary Speech, Ps.-Martyrius attempts to transform John into a martyr and a saint. The speech was written around 407 by an unnamed supporter of John and focuses primarily on the events leading up to John's expulsion from Constantinople. ${ }^{5}$ Similar in style to Gregory of Nazianzus's panegyric on Athanasius of Alexandria, the Funerary Speech includes the details of John's early life but emphasizes his exile in order to laud John's efforts to promote and preserve orthodoxy. For example, John's involvement in the Gainas affair plays a definitive role in the early sections of this account. ${ }^{6}$ Gainas, a Gothic general commanding troops in and around Constantinople, appealed to the emperor Arcadius in an effort to secure the right to worship inside of the city limits. Although more well known elsewhere as a "barbarian," Ps.-Martyrius's text describes Gainas as an Arian bent on invading

4. For a comprehensive evaluation of the Origenist controversy, see Clark, Origenist Controversy. For a recent examination of Palladius's involvement in the controversy as it pertains to his Dialogue, see Katos, Palladius of Helenopolis.

5. See T. D. Barnes, “The Funerary Speech for John Chrysostom (BHG3 $871=$ CPG 6517)," Studia Patristica 37 (2001): 328-45. Barnes argues that the author is a deacon by the name of Cosmas, although this argument is contested, and the pseudonym Ps.-Martyrius remains the key identifier of the author. Wallraff and Ricci argue the author is Philip of Side; see Wallraff and Ricci, Ps.-Martyrius, 27n11. The structure of the text is carefully dissected by Florent van Ommeslaeghe, "De lijkrede voor Johannes Chrysostomus toegschreven aan Martyrius van Antiochie: Tekstuitgave met commentaar, hoofdstukken uit de historische kritiek" (PhD diss., Katholieke Universiteit te Leuven, 1974); and van Ommeslaeghe, "La fête de S. Jean Chrysostome dans l'église grecque," Analecta Bollandiana 96 (1978): 38.

6. The account is also mentioned in Socrates, Eccl. Hist. 8.7, and Sozomen, Eccl. Hist. 6.5. 
and overtaking the city. John successfully convinces Arcadius to refuse Gainas, and this is described as a decisive win for Nicene orthodoxy (Fun. Orat. 24-26).

Although often apologetic in nature, the bulk of the speech serves as an invective against John's two chief enemies: Theophilus of Alexandria and the empress Eudoxia. Ps.-Martyrius characterizes Theophilus as a villainous and irascible patriarch. What he takes issue with is not Theophilus's orthodoxy but his political activities, which Ps.-Martyrius saw as dishonoring his role as a bishop. Elm states, "The Theophilus portrayed by Ps.-Martyrius is not a likeable character either, but rather than the abject villain portrayed by Palladius, we find here a man who was a shrewd politician and excellent power-broker, quick to forge and dissolve alliances without being overtly impeded by scruples." 7 Ps.-Martyrius highlights Theophilus's violent treatment of the Tall Brothers, for example, but the Origenist controversy is clearly not his chief concern.

The role of chief opponent and heretical threat in this text is instead reserved for the imperial matriarch. T. D. Barnes addresses Ps.-Martyrius's choice of an imperial literary foil, noting that a standard schema is used to describe rulers who persecute the faithful: the persecutor is afflicted by a painful illness, worms consume him, and then, in pain, he acknowledges his error and is permitted to die. ${ }^{8}$ The deaths of Antiochus IV of Syria (2 Macc 9:5-28) and King Herod Agrippa serve as popular models within Jewish texts. For example, in Flavius Josephus's Jewish War, we find a detailed description of Herod's untimely end:

After this, the distemper seized upon his whole body, and greatly disordered all its parts with various symptoms; for there was a gentle fever upon him, an intolerable itching over all the surface of his body, continual pains in his colon ... and a putrefaction of his privy member, that produced worms ... when he sat upright, and had a convulsion of all his members. ... The diviners said those diseases were a punishment upon him for what he had done to the Rabbins. ${ }^{9}$

Elizabeth Castelli draws attention to the use of this literary schema in later Christian invectives. ${ }^{10}$ Gruesome medical conditions are a frequent form of fantastical retribution in Lactantius's Death of the Persecutors, in which, for example, Galerius, like the infamous Nero, sets fire to the city and blames it on the Christians; a painful gastrointestinal disease is the consequence of this poor choice. Lactantius described for his readers how the cancerous ulcer slowly rots away the emperor's intestines: "As the marrow was assailed, the infection was forced inwards, and got hold of his internal organs; worms were born inside him. The smell pervaded not

7. Elm, "Dog," 76.

8. Barnes, "Funerary Speech," 336.

9. Flavius Josephus's Jewish War 1.656. Translation: William Whiston, The Works of Flavius Josephus: Complete and Unabridged (Peabody, MA: Hendrickson, 1989), 596.

10. Elizabeth Castelli, "Religious Identity through the Prism of Spectacle in Early Christianity" (paper presented at the Symposium on Identity in Late Antiquity, Duke University, February 20, 2009). 
just the palace but the whole city; and this was not surprising, since the channels for his urine and excrement were now confused with each other. He was consumed by worms, and his body dissolved and rotted amid insupportable pain" (Mort. 33.6-8). ${ }^{11}$ The pain was so excruciating, Lactantius reported, that it compelled him to cry out to God, saying "that he would restore the temple of God and make satisfaction for his crime" (Mort. 33.11). It was only after he kept Christians from further persecution that his disease finally eased into death. Lactantius carefully dissected the body of the persecutor to display before his readers the internal corruption of the tyrant. Each detail penetrates the reader's senses: we hear the guilty cry out, we smell the bodily decay, and we see their insides burst forth in a display of their guilt.

Retributive schemas and vivid depictions of human suffering and gore such as these surface in heresiological texts later in the fourth century as well. As Ellen Muehlberger has noted, Arius's illness and death were frequently commented upon. ${ }^{12}$ In his Letter to Serapion concerning the Death of Arius, Athanasius of Alexandria invoked execrable images similar to those engaged by Lactantius. Only moments before Arius is supposed to be received back into communion with the church, Athanasius gleefully reported, "a wonderful and extraordinary circumstance took place.... Arius, who had great confidence in Eusebius and his fellows, and talked very wildly, [was] urged by the necessities of nature [and] withdrew, and suddenly, in the language of Scripture, 'falling headlong he burst open in the midst,' and immediately expired as he lay, and was deprived both of communion and of his life together."13 The phrase "burst open" (elakēsen) links Arius to the death of Judas Iscariot in Acts 1:18, which reads, "Now this man [Judas] obtained a field with the reward for his wickedness, and falling headlong, his body burst open and all his intestines gushed out." Both Arius and Judas Iscariot are deprived of mercy, and their bodies are unable to contain the error within them, so their corrupted bodies are cut off from communion with the church.

It was popular after the second half of the fifth century to imagine heresy as a disease. ${ }^{14}$ These Christian etiologies of heresy proved to be an effective means

11. Edition: SC 39, 115. Translation: J. L. Creed (ed. and trans.), Lactantius, De Mortibus Persecutorum, Oxford Early Christian Texts (Oxford: Clarendon, 1984).

12. See Ellen Muehlberger, “The Legend of Arius' Death: Imagination, Space, and Filth in Late Ancient Historiography," Past and Present 277 (2015): 8-10. Muehlberger traces how the story of Arius's death is co-opted into different ancient historiographical projects from the 360 on. The details of how and where Arius dies shift in order to meet the needs of different Christian authors. For example, she compares the emphasis on the exposure of Arius's shame in a public toilet in Rufinus, Eccl. Hist. 10.14, with the added spectacle of his death out in the open, near the porphyry column, in Socrates, Eccl. Hist. 1.38.7.

13. Athanasius, Ep. mort. Ar. 3. Edition: Hans-Georg Opitz (ed.), Athanasius Werke 2, Band 1, Erster Teil: Die Apologien (Lfg. 1-7) (Berlin: de Gruyter, 1940), 178-80. Arius's death is also reported in Socrates, Eccl. Hist. 2.38. Epiphanius also describes Arius's death with reference to Judas, see his Pan. 68.6.9.

14. See, e.g., John Rufus, Plerophories, 26, 40, 65. An earlier link between the rhetoric of psychagogy in philosophical traditions and medical imagery in New Testament texts treats diseased souls and 
of identifying the impious and reimagining how the enemies of God were punished. ${ }^{15}$ By overlapping the medical with the theological, Christian authors also helped their readers to distinguish the guilty from the innocent. This growing trend took a troubling turn once the pregnant body of a persecuting empress became the target of Christian invective. Ps.-Martyrius's description of Eudoxia's punishment for her involvement in John's two exiles makes this link all the clearer.

Eudoxia remains an infamous character within Christian memory, as Wendy Mayer has noted. ${ }^{16}$ Her involvement in John's first exile is not detailed in this text, but one presumes the empress is at least complicit with the imperial strength used to ensure John's initial departure from the city. It is only from other biographical sketches that we learn more about her particular influence. The fifth-century historians Socrates and Sozomen, for instance, claim that Eudoxia called for John's second exile after an inflammatory sermon he gave chastising the empress. ${ }^{17}$ According to later Byzantine vitae, however, it was John's criticism of her effort to confiscate a poor widow's vineyard that prompted the empress's actions, which clearly link her to Jezebel. ${ }^{18}$ Barnes and Bevan have recently suggested that the strife between the empress and John actually arose from John's sharp critique of imperial politics, especially as they related to the treatment and subsequent execution of the powerful eunuch Eutropius in $399 .{ }^{19}$

appears to underline much of what Christian authors view as the corruptive nature of heresy; see A. Malherbe, "Medical Imagery in the Pastoral Epistles," in Texts and Testaments: Critical Essays on the Bible and Early Church Fathers in Honor of Stuart Dickson Currie, ed. W. Eugene March (San Antonio, TX: Trinity University Press, 1980), 19-35; and M. Nussbaum, "Therapeutic Arguments: Epicurus and Aristotle," in The Norms of Nature: Studies in Hellenistic Ethics, ed. M. Schofield and G. Striker (Cambridge: Cambridge University Press, 1986), 31-74.

15. For a discussion on the infection of worms in tyrants, see T. Africa, "Worms and the Death of Kings," Classical Antiquity 1, no. 1 (1982): 1-17. The most famous etiology of heresies is list of heresies and prescribed cures in Epiphanius of Salamis's Panarion. For a recent discussion of the overlap of heresy and disease, see P. Mena, "Insatiable Appetites: Epiphanius of Salamis and the Making of the Heretical Villain," Studia Patristica 67 (2013): 257-64; and R. Flower, "Genealogies of Unbelief: Epiphanius of Salamis and Heresiological Authority," in Unclassical Traditions, volume 2: Perspectives from East and West in Late Antiquity, ed. Christopher Kelly, Richard Flower, and Michael Stuart Williams (Cambridge: Cambridge Philological Society, 2011), 70-87.

16. Mayer, "Doing Violence." Eudoxia's reputation is often marred by her perceived involvement in John's exile. See also Mayer, "Constantinopolitan Women."

17. Socrates equated Eudoxia with the infamous Herodias in Mark and Matthew's gospel. He exclaimed: "Herodias rages madly again, dances again and again seeks to receive the head of John on a platter" (Socrates, Eccl. Hist. 6.18.1-6). Ps.-Martyrius, however, favored the equally slanderous Jezebel. Sozomen, Eccl. Hist. 8.16, 20, contain his records of the ill-fated speeches.

18. K. G. Holum, Theodosian Empresses: Women and Imperial Dominion in Late Antiquity (Berkeley: University of California Press, 1982), 48-78. The link to Jezebel is discussed further below.

19. See Barnes and Bevan, Funerary Speech, xi. They go on to argue that this criticism appears to have put him at odds with the royal couple to such an extent that Arcadius and Eudoxia have their son, Theodosius, baptized by Severianus of Gabala, as a public sign of their rejection of John's authority; 
Although Arcadius could easily have also played the role of persecuting despot in the Funerary Speech, Ps.-Martyrius focused almost exclusively on Eudoxia. It remains to be seen why he would favor an invective solely against the empress and not the emperor as well. Retributive literature frequently aligned punitive illness with male rulers. ${ }^{20}$ At first glance, we might assume that the woman with power was singled out because she fully embodied the role of the persecuting imperial figure. If we look closer, however, we see that her body contained a more grievous error and made her experience akin to the fate of Arius.

In a charged moment of the narration, John's first exile ends immediately after Eudoxia's miscarriage:

I will not willingly hide the symbol of the Lord's anger at what was done ... knowing that the root of all evil had been concealed [tès kakias apasēs hè rhiza apokekryptai] in the woman who exercised power, [he then] released his hand. The arrow flew and hit the stomach of the wretched woman, reminding her and saying: "Woman, in pain will you give birth to children" [Genesis 3.16], sending them forth from your stomach straight to the grave, mixing with the first swaddling clothes the final burial shroud and becoming in one instant both a mother and childless. (Ps.-Martyrius, Fun. Orat. 66 $)^{21}$

This striking passage reveals several details about John's imperial enemy. First, the body of the empress is the explicit target of God's anger. Her husband is not to blame, and neither is the Alexandrian bishop Theophilus-at least not yet. Second, the arrow strikes her body and instantly kills the root of all evil within her. ${ }^{22}$ And,

later pro-Johanite sources omit this event entirely. The link to children appears to support the message conveyed in this account. See note 24 below on the death of Jezebel's children.

20. The notable exception is found in a much older source: Herodotus's Histories. He references the death of the queen of Cyrene, Pheretime, whom the gods punish with a comparable disease because she used excessive force against her enemies, impaling the chief instigators of her son's murder and cutting off the breasts of their wives. Herodotus notes, "Pheretime ... died an evil death, having become suddenly full of worms while yet alive; for, as it seems, too severe punishments inflicted by men prove displeasing to the gods" (Herodotus, Hist. 4.205). As we will soon see, Eudoxia’s body was also overcome with worms.

21. The translation here has been altered for reasons I explain in greater detail below in note 32. I translate gastros as "womb," but the most common terms in medical literature are mêtra, "womb," or hystera, "uterus." If we follow the retributive literature from which this text is drawing, then gastros should be translated as "belly" or "stomach." Barnes and Bevan translate this term as "stomach" in other passages in the text, which I explore in detail later in this chapter.

22. Ps.-Martyrius here appeals to the classical trope of poisoned arrows from the gods. Divine beings were known to use poisoned arrows as punishment. Poisoned arrows are also an ambivalent symbol. They kill off many monsters in Greek myth, but they also injure innocent bystanders: e.g., the death of the centaurs Chiron and Pholus (Ps.-Apollodorus, Biblio. 2.83-87). It appears that even the most powerful heroes and villains are vulnerable to poisonous arrows. The most famous example is Heracles, who kills with poisonous arrows and is himself killed by one (indirectly). For a popularized version of his death, see Ovid, Metam. 9.134-272, and Her. 9. 
finally, the episode ends with a damning reference to Eve's curse. This revealing biblical link emphasizes that the empress's body is predisposed to error, a frequent claim regarding both women and heretics. Nosological treatises also consistently stress that the constitution of the patient determines a proper diagnosis. ${ }^{23}$ Both biological and external factors must be taken into account to read the disease. In this instance, Eudoxia's cursed body and the poisoned arrow results in a painful and deadly disease that kills the evil growing inside her.

Ps.-Martyrius makes use of other typological links as well. He frequently refers to Eudoxia as Jezebel (Ps.-Martyrius, Fun. Orat. 3; 6; 138), the infamous matriarch of the Northern Kingdom who exiles the prophet Elijah (1 Kgs 19). ${ }^{24}$ This second biblical link further supports the idea that Eudoxia promoted competitive Christian factions in and around Constantinople. ${ }^{25}$ Readers attuned to the biblical narrative might recall that Jezebel's first son, Jehoram, died from an arrow wound (2 Kgs 9:19-21). The comparison was clearly not lost on Ps.-Martyrius. ${ }^{26}$

The Funerary Speech also evokes classical myths. The myth of Niobe, the queen of Thebes, would have been familiar to Ps.-Martyrius's readers. Ovid, for example, recounted how Niobe's taunting of the goddess Leto draws the wrath of the gods. Her children are subsequently hunted down and killed by the poisoned arrows of Leto's children, Apollo and Artemis. ${ }^{27}$ Both the hubris of nefarious women and the original mother's curse place Eudoxia within a long line of deviant mothers, as well as persecuting despots.

After she miscarries (and is sufficiently humbled), Eudoxia immediately calls for John's return. She even attempts to personally reinstate him as the bishop of

23. The Hippocratic author of Airs, Waters, Places, for instance, emphasizes the role that the constitution of the sufferer plays in diagnosis (Hippocrates, Aer. 9). According to Ps.-Martyrius, this predisposition appears to be the case with women, all of whom fall under the curse of Eve, which is discussed in later detail in this chapter.

24. Jezebel was a more threatening power than her husband, Ahab, and promoted the worship of the god Baal. For a discussion on Jezebel's afterlife, see T. Pippin, "Jezebel Re-Vamped," in A Feminist Companion to Samuel and Kings, ed. A. Brenner, Feminist Companion to the Bible (Sheffield, UK: Sheffield Academic, 1994), 196-206. For a description of the gendered pairing, see P. Trible, "The Odd Couple: Elijah and Jezebel," in Out of the Garden: Women Writers on the Bible, ed. C. Büchmann and C. Spiegel (New York: Ballantine, 1994), 166-79. Eudoxia's second miscarriage might also be linked to Jezebel's daughter, Athalia, who was married to the corrupt king of the Southern Kingdom, Jehoram (n.b., this Jehoram is not the same as Jezebel's first son, also named Jehoram). Athalia is also described as corrupt ruler, but it is her husband, Jehoram, who dies from a disease of the bowels. The disease described mirrors Eudoxia's second miscarriage. Like Eudoxia's, his bowels are painfully expelled from his body (2 Chron 21:19-21). While Jezebel's progeny die as adults, there may be a loose allusion here to Eudoxia's supposed culpability as the mother of whores.

25. The empress's alliances with the bishop Arsacius (d. 405) and his successor, Atticus (d. 423), John's rivals, are frequently remarked upon throughout the text.

26. Mayer, "Doing Violence," 206-8.

27. See, e.g., Ovid, Metam. 6.146-312. These arrows were particularly deadly and resulted in a swift death. 
Constantinople. Yet John, Ps.-Martyrius insists, would not willingly take back his see without the consent of a council; readers are reminded that the empire does not hold any jurisdiction in matters of faith. It is only after an unnamed council clears John of Theophilus's false charges that he agrees to return to his bishopric. ${ }^{28}$

Yet John's return is only temporary. Ps.-Martyrius reports, "He [the Devil] caused the woman who wielded power to forget the earlier blow and introduced in its place a deep hatred, which was without any trouble, planting many lies through many mouths" (Fun. Orat. 4, emphasis mine). As forgetfulness sets in and the many lies take root in what would be her last pregnancy, the empress calls for John's last exile. For a final time, then, John leaves Constantinople, and, as Ps.-Martyrius narrates, the entire city suffers as a consequence. Bereft of its true father, the church is burned, and, as Nathaniel Andrade has noted, all spiritual life departed from the city along with the bishop. ${ }^{29}$

With the city ablaze, fatherless, and devoid of spirituality, Ps.-Martyrius turns his gaze once again to the fecund mother and says, "another arrow of the Lord again hit the woman, no longer saying 'in pain,' but 'in death, woman, shall you bear children' [Genesis 3.16]" (Ps.-Martyrius, Fun. Orat. 121). Eve's story is once again read through the body of the empress, but the root of evil is replaced with a horrific monstrosity. Unlike her previous crime, for which she was justly punished, this final pregnancy is significantly different. It is no longer the simple pride of a monarch or the stain of Eve's disobedience that gestates within her, but an all-consuming excrescence that must be pierced by another arrow. But this second arrow releases a powerful disease. Ps.-Martyrius remarks, "[The arrow] loosed against her a painful and many-headed illness [nosma polykephalos] that virtually spoke: 'This is the finger of God'" (Fun. Orat. 121). The arrow that strikes Eudoxia in the first instance kills the root of evil growing within her. This second attack lets loose a disease that devours her from the inside out. What Eudoxia carries within her is much more dangerous than before.

In order to reveal the growing monster within and the epic battle waged by this disease, Ps.-Martyrius draws us into a detailed and elaborate account of Eudoxia's suffering:

28. John is once again removed from his position on the grounds that a second council could not be lawfully adjudicated after an initial deposition was been made. Ps.-Martyrius cites a law instituted after Athanasius's deposition thought to be carried over with Theophilus from Alexandria. Canon 5 from the Council of Nicaea states, "Concerning those, whether of the clergy or the laity, who have been excommunicated, the sentence is to be respected by the bishops of each province, according to the canon that forbids those expelled by some to be admitted by others. But let an inquiry be held to ascertain whether anyone has been expelled from the community because of pettiness or quarrelsomeness or any such ill nature on the part of the bishop." Edition: Alberigo et al., Conciliorum Oecumenicorum Generaliumque Decreta, and PG 47 2.9. Translation mine.

29. Nathaniel Andrade, "The Processions of John Chrysostom and the Contested Spaces of Constantinople," Journal of Early Christian Studies 18, no. 2 (2010): 161-89. 
See: there was a dead fetus in her, buried in its mother's cavities, which, by blocking the passage of foods, turned what was recently ingested in nauseous bile and forced the bitter fluid to rush back up to her throat, and thrust what had long lain dead downwards by the weight of the body with a great rushing. Next, as may be expected to happen with a dead body, floods of worms teemed forth, some quivering on top of the head of the unseen corpse and causing vomiting of the undigested food; others under its feet making the flux of the belly sharper and painful; and some, on occasion, creeping out with the mass of blood flowing forth. In addition, a fever seized the whole of the rest of her body, so close to fire that it shone, and all sleep, as you know, shuns the eyes of the delirious (Fun. Orat. 121). ${ }^{30}$

Eudoxia's stomach is flooded with the most nauseating of concoctions. As this glimpse into the birthing chamber shows, her torment follows a familiar pattern to the stomach ailments of those persecuting emperors before her: her intestines [along with her child] rot, spewing forth worms; sharp pains overcome her; and her body is racked by a fever. Like her male predecessors, she is fully conscious of every stage of her torment.

What stands out in this section of the speech is that Ps.-Martyrius avoids any description of gynecological disease..$^{31}$ The Greek term for "womb" is absent from both descriptions of Eudoxia's body being struck by the arrows of God. We are certainly aware that she is pregnant, because the outcome of each strike is described as a miscarriage. But Ps-Martyrius favors the more generic term gastros, "stomach, belly" to describe the target..$^{32}$ Particularly in this second scene, Ps.-Martyrius

30. I have altered the translation by Barnes and Bevan to more accurately convey the ambiguous nature of the fetus and what Ps.-Martyrius suggests is actually rooted within Eudoxia's body. If Ps.-Martyrius is using medical theory related to fetal development, the fetus has no independent agency until at least the eighth month of pregnancy; see A. E. Hanson, "The Gradualist View of Fetal Development," in Lembryon: formation et animation; antiqué grecque et latine tradition he'braï, chrétienne et islamique, ed. L. Brisson, M.-H. Congourdeau, and J.-L. Solère (Paris: Librairie Philosophique, 2008), 96-97.

31. For a discussion on different gynecological diseases related to the womb, see C. Faraone, "Magi$\mathrm{cal}$ and Medical Approaches to the Wandering Womb in the Ancient Greek World," Classical Antiquity 30, no. 1 (2011): 1-32. There is quite a bit of discussion in the Hippocratic corpus and medical literature at large (from Plato to the more contemporaneous doctors of late antiquity) on the relationship between the "wandering womb" and the "sacred disease." Faraone (3) argues that the wandering womb provokes diseases: the "womb was not the site of disease but rather the cause of spasmodic disease in other areas of the body." As many have argued, male and female bodies are often divided and treated separately within ancient medical literature. A series of gynecological texts was created to account for this difference. The Hippocratic corpus devotes an entire treatise to these particular gendered issues; see H. King, Hippocrates' Women: Reading the Female Body in Ancient Greece (New York: Routledge, 1998), 21-39; and the translation and introduction to the Diseases of Women by A. E. Hanson, "Hippocrates: 'Diseases of Women 1,'” Signs 1, no. 2 (1975): 567-84.

32. This term does have a semantic range that includes "womb." It appears that the choice made by Barnes and Bevan to translate gastèr as such is tied to their understanding of John's interactions with Eudoxia and her children; see Barnes and Bevan, Funerary Speech, 25-28, sections 8.1 and 8.2. Ps.-Martyrius's contemporaries also compare the empress to Jezebel. 
intentionally distances Eudoxia from her sex and queers her gender to fit her within the long line of persecuting emperors. ${ }^{33}$ The disease that pierces and takes over her body is a gastrointestinal one that places her firmly within the retributive tradition. ${ }^{34}$ For our purposes, it is worth noting that according to various medical texts, these diseases not only frequently result in horrific pain and are troublesome to treat, but they are also extremely difficult to diagnose, because they remain hidden from view. ${ }^{35}$

While it is clear that Ps.-Martyrius makes full use of the retributive tradition, a few notable differences do stand out. ${ }^{36}$ We are reminded of the reason for Eudoxia's excessive torment. When she cries out in pain in this second scene, she calls out not to God, but to John: "Why do you attack me, John?" Her suffering is thus tied directly to the suffering of the exiled bishop. This connection to John's experience-and, as we will soon learn, his reputation-requires the divine to take matters into his own hands.

Ps.-Martyrius again relies on classical tropes to explain why such a disease is required to punish Eudoxia: it is what she carries that makes her such a dangerous threat. The description of the battle that takes place within her recalls the second labor of Heracles, in which he defeats the many-headed serpent, the Lernean hydra. ${ }^{37}$ After shooting flaming arrows at the beast, Heracles grabbed the hydra

33. Another queering takes place when John and his rival are compared to the two mothers in $1 \mathrm{Kgs} 3: 16-28$. John cares for his child(ren) and is characterized as the true mother who proved her (his) legitimacy when she (he) willingly handed over her (his) child in order to save it from being cut into two. See Ps.-Martyrius, Fun. Orat. 128-29.

34. Stomach ailments are particularly notable in ancient medical literature. Discussions pepper the Hippocratic corpus; see, e.g., Hippocrates, Aer. 7 and Acut. 17. These diseases are also particularly prevalent throughout Pliny, Nat. For his discussion on various diseases and treatments, see esp. Pliny, Nat. 30.19-23.

35. Nosological treatises, such as the Hippocratic Sacred Disease and Acute Diseases, place a particular import on the need for careful diagnosis, especially when the effects of the diseases are not visible.

36. This includes John Chrysostom's narration of exploding bodies and other texts such as the death of Julius Julianus, the uncle of Julian the Apostate, in his martyrology on St. Babylas. I will discuss St. Babylas in more detail in the next chapter. This foolish man unwisely decided to first touch the relics with a defiled hand then decided sit on the remains of the martyr. John writes, "Immediately, he paid the penalty for this unlawful session: his genitals became putrefied and generated worms. That the disease was sent by God is shown by this fact: when physicians killed luscious rare birds and placed them next to the putrefied members to elicit the worms, they did not emerge but clung tenaciously to the rotten parts, and he perished after many days" (Bab. 92). Edition: SC 362, 90-274. Translation: Margaret Amy Schatkin and Paul W. Harkins (trans.), Saint John Chrysostom: Apologist, FC 73 (Washington DC: Catholic University of America Press, 1983).

37. Several references to the second labor of Heracles circulated in and around Constantinople; see Diodorus Siculus, Hist. 4.11.5; Ps.-Apollodorus, Biblio. 2.77-80; and Ovid, Metam. 9.69 ff. As he proves throughout the course of his twelve labors, Heracles is the ultimate slayer of monsters. His cult was widespread in late antiquity. The tragedy Herakles, for example, composed by Euripides and then later adapted by Seneca as the Hercules Furens, was frequently performed in the theaters and depicted in the material culture of Constantinople. For the performance of material culture, see Ismene 
as it wrapped itself around his foot. As Hercules chopped off each of the hydra's heads, multiple regenerated heads would appear in its place, making the hydra a difficult monster to defeat. To prevent regrowth, Heracles has his companion, Iolaos, burn the sinews of each neck..$^{38}$ When the beast is finally defeated, Heracles dips his arrows into the venomous blood of the monster. In later labors, he uses the arrows to defeat his enemies. A simple touch of the arrow results in a burning sickness that attacks the body and lets off a putrid smell. ${ }^{39}$ Ps.-Martyrius, certainly familiar with this popular tragedy, weaves in several narrative strands to describe the war waged within Eudoxia. The many-headed lies growing within the empress required a many-headed illness to kill it. Similar themes such as the hero's hand, the burning fever, and the putrid smells invoke familiar visceral, literary links in Ps.-Martyrius's description of Eudoxia's bedroom struggle.

Ps.-Martyrius also evokes this familiar story to reveal to his readers what has taken root in Eudoxia. The many-headed lies are tied to the circulating rumors of John's collusion with and protection of known heretics. Heresy as a disease-a description favored by John Chrysostom himself-is particularly pernicious, as it spreads quickly and is hard to kill. Other heresiologists, such as Epiphanius of Salamis, also describe heresy as a "many-shaped monstrosity" (Epiphanius, Pan. 30.1.1). ${ }^{40}$ To kill off even the rumor of heresy requires the drastic intervention of the divine. ${ }^{41}$ These rumors, or lies, gestate within the empress. Her very person

Lada-Richards, “'By Means of Performance’: Western Greek Mythological Vase-Paintings, Tragic 'Enrichment, and the Early Reception of Fifth-century Athenian Tragedy," Arion 17, no. 2 (2009): 99-166. For Seneca's interpretation of Heracles's madness, see Anna Lydia Motto and John R. Clark, "The Monster in Seneca's Hercules Furens," Classical Philology 89, no. 3 (1994): 269-72. Two statues of Heracles were believed to be present in the hippodrome in Constantinople; see Albrecht Berger, "Herakles and the Hippodrome of Constantinople," in Hippodrom/Atmeydani: İstanbul'un Tarih Sahnesi, ed. Brigitte Pitarakis (Istanbul: Pera Müzesi, 2010), 194-205. Later Byzantine hagiography (e.g., the Halkin (or Patmos)-Vita) would depict Constantine as a type of Heracles who defeats several trials at the court of Galerius; see Samuel Lieu and Dominic Montserrat (eds.), From Constantine to Julian: Pagan and Byzantine Views: A Source History (New York: Routledge, 1996), 102.

38. Heracles gains sole credit for the defeat of hydra in Euripides, Her. 154.

39. Ironically, Heracles is infected later with this same poison, and it is the cause of his own death; see Ps.-Apollodorus, Biblio. 2.157; Ovid, Metam. 9.129, 158. Two accounts use the story of centaur(s), who is shot by one of Heracles's arrows washed his poisoned wound in the Anigros. This story is used to explain why the river emits such a horrific odor; see Strabo, Geog. 8.3.19; and Pausanias, Descr. 5.5.9. The waters were also supposed to have healing powers, and many lepers came to be healed there, according to Strabo: "The baths here cure leprosy, leuke, and leichene"; see Duane Roller, The Geography of Strabo: An English Translation, with Introduction and Notes (Cambridge: Cambridge University Press, 2014), 348.

40. See Andrew Jacobs, Christ Circumcised: A Study in Early Christian History and Difference (Philadelphia: University of Pennsylvania Press, 2012), 105. Jacobs highlights this phrase found in Epiphanius's description of the Ebionite heresy.

41. Ps.-Martyrius is stepping outside of convention in several ways. This is a curious twist on the popular image of God as good physician. Here he introduces a retributive disease to cure the disease of heresy. It does not cure Eudoxia but is intended to heal the church (and restore John's reputation). To kill 
threatens to reproduce them and possibly create still more. What is even more remarkable is that, instead of finding care in the hands of a competent midwife, Eudoxia is pierced by the finger of God (daktylos theou) and suffers grievously.

Yet, Ps.-Martyrius disdainfully remarks, Eudoxia does not repent and die. Like the pharaoh of Exodus, her heart is hardened, and she makes no attempt to recall John from exile as she did before. Writhing in pain, she obstinately summons John's rival, Arsacius, to her bedside instead. Eudoxia brazenly receives the Eucharist and, Ps.-Martyrius exclaims, "this was the only sin she had not yet committed" (Fun. Orat. 121). Ps.-Martyrius then uses grotesque imagery to draw the reader's eye to what is typically hidden from view:

[Eudoxia] seized the infant, and she quickly vomited out her soul along with the communion. Still breathing and half-alive, she filled the sensory organs of those standing by her with an evil stench surpassing the plants of India and the flies of Persia, ... her suffering hinting at nothing else than that $<$ it $>$ had long been among the dead things. In this way she brought her life to a close. (Ps.-Martyrius, Fun. Orat. 121) ${ }^{42}$

The violence of this spectacle grabs our senses. We see the fetus clutched in her arms, we hear her vomit out both soul and Eucharist, and we smell the stench emanating from her belabored breaths and the decaying bodies. Ps.-Martyrius makes visible through Eudoxia's second miscarriage and in her postmiscarriage emesis the corruption of both the body and the soul. ${ }^{43}$ In her pursuit of the cleansing perfection of a deathbed absolution, she perfects her sinfulness. The only evidence of holiness is vomited out, and, like that most notorious heretic, Arius, Eudoxia is successfully cut off from the church.

These textual (and gendered) allusions made by Ps.-Martyrius, if we can assume they are indeed at play here, serve a similar purpose to those employed by Cyprian of Carthage. Sonja Anderson has recently shown how Cyprian made ample use of this violent bodily rejection of the Eucharist in his text The Lapsed to reveal what is often hidden. Her observations point to the functionality of the Eucharist as both judge and judgment. ${ }^{44}$ She highlights two sections in the text where lapsed

a disease with another disease is also an aberration in the medical tradition, although not without some support. See, e.g., the reference to hemorrhoids, which are said to cure melancholia, mania, and nephritic affections (Hippocrates, Aph. 4.11, 21). My thanks to Richard Flower for pointing out this reference.

42. "Kai toutōn ontōn en toutois ekeinē to brephos katelambane, tacheōs tē koinōnia synexemesasa tēn psychēn. tosautēs de eneplēse ta tōn parestēkotōn aithētēria dysōdias, empnous epi kai hypozōos ousa, hōste nikasthai kai ta Indias phyta kai tous Perikous myas hapasan te . . . ouden heteron tou pathous ainittomenou ē hoti palai en nekrois etynchane. kai houtō dē katalyei ton bion." (Wallraff and Ricci, Ps.-Martyrius, 523b-524b, with slight emendation).

43. Ps.-Martyrius may be gesturing here to John Chrysostom, Catech. illum. 2.2. Edition: PG 49. 233. This is a catechetical sermon in which he describes how the mouths of the wicked defile the Eucharist.

44. These observations were made by Sonja Anderson, "Discerning the Body in Cyprian's De Lapsis" (paper presented at the North American Patristics Conference, Chicago, May 27, 2017). Many thanks to her for allowing me access to this paper. 
Christian women, in particular, are administered the Eucharist but are unable to stomach the rite. In the first case, we hear about an infant who was left behind by her Christian parents during the height of the Christian persecutions. During their departure, the baby was exposed to food and drink meant for idols without the parents' knowledge. After they returned and recovered their child, they brought the corrupted infant to church. When she was forcibly given the elements, the baby could not hold anything down. Cyprian describes the scene as such: "The Eucharist could not remain in a body or a mouth that was defiled; the drink which had been sanctified by Our Lord's blood returned from the polluted stomach. So great is the power of the Lord, so sacred His majesty; under His light the hidden corners of darkness were laid bare, even secret crimes did not escape the priest of God" (Cyprian, Laps. 25).

Cyprian's second scenario involves a youthful woman who attempts to slip by unnoticed. It is not entirely clear what her crime may have been, but it appears Cyprian accuses her of being a false Christian, who, like the empress, is unable to hide her internal error. And the outcome of this crime was no less poisonous:

It was not food that she took so much as a sword against herself, and what she swallowed might have been some deadly poison entering her breast. After the first spasms, struggling for breath, she began to choke and, a victim now not of the persecution but of her own crime, she collapsed in tremors and convulsions. The guilt which she had tried to hide did not remain long unpunished or concealed. If she had deceived man, she was made to feel the avenging hand of God. (Laps. 26) ${ }^{45}$

In Ps.-Martryius's Funerary Speech, the Eucharist functions as a revealer not only of duplicity, as in these examples from Cyprian, but also of heresy, even when Christian flight appears to place the blame upon those who flee. In the case of both Ps.-Martyrius and Cyprian, the author shifts our focus away from the true Christians in flight (read fleeing bishops) and back toward those who remain and try to pass as righteous. Only the hand of God or his physical presence in the elements proves otherwise.

This final scene in the Funerary Speech reveals that Eudoxia is not simply a persecuting empress, although she has certainly proven that she holds court among the most notorious of emperors. Her suffering in this second miscarriage mirrors the gastrointestinal diseases of her heinous imperial predecessors; her heretical counterpart, Arius; and even the duplicitous female members of Cyprian's lapsed community. Ps.-Martyrius concludes that what Eudoxia harbors is nothing short of a hidden war against the church (Fun. Orat. 122). Even more insidious for him is that error she houses within her body, an error which threatens John's legacy: the charge of heresy. She carries not a child but "the many lies spread through many mouths" (Fun. Orat. 4). It is a contagion of error that is initially hidden from view.

45. For a possible intertextual link, see my description of the trope of true martyr (Polycarp) versus the false martyr (Quintus), discussed in the prologue. 
We are made aware of its corrupting power only after the divine introduces the many-headed illness that consumes Eudoxia's body from the inside out and when her body physically rejects the Eucharist.

Ps.-Martyrius laments that the cause of Eudoxia's suffering is not readily apparent to the casual observer. We find this point reinforced by the inconsistent rumors surrounding John's death. One rumor stands out among the rest: John, too, dies of an unknown illness aggravated by his travels in exile. ${ }^{46}$ After news of the bishop's death spreads, Atticus-John's rival and Arsacius's replacement-dons the robes of bishop. He travels about the city attempting to win over those who had supported John and to ease the tensions that had arisen after his final exile. Ps.-Martyrius berates Atticus's efforts and calls him a false physician:

Tyrant ... with what objective in view do you apply medications to wounds that you have inflicted? Or, because you know how to flatter, did you deliberately cause pain before so that you might have an opportunity to practice your skill, acting exactly like a doctor who, having gathered countless herbs and fastened them with a rag, might carry this in his left hand, strike a man with a club in his right hand and say to him: "Cheer up, my dear friend, I have the remedy in my hands." (Fun. Orat. 137)

Here the medical mingles here with the theological once again. We find several arguments on the danger of false physicians in the Hippocratic corpus. Chief among the characteristics of false physicians is the intentional harm they cause their patients. ${ }^{47}$ It therefore remains unclear who the true impostor might be. John dies as an accused heretic in exile, while his rival walks free.

Ps.-Martyrius's exilic discourse is dependent upon the city-centered exilic discourse of John himself. Individual places in the city, such as the bedroom or the throne room, are transformed by those who inhabit them. The buildings and public gathering places are also miraculously changed by those given the authority to control them. The Gothic general Gainas is again an excellent example of the threat heresy posed to the citizens of Constantinople. His desire to use a church inside the city limits might infect all the other buildings in turn. Walls do not just make Christians; they make heretics as well, as Athanasius argued before. ${ }^{48}$

46. Ps.-Martyrius reports that his death was "brought about not by iron, but by what was much more cruel than iron-long forced marches and illness imposed on the natural frailty of the body" (Fun. Orat. 135). As Andrew Crislip has pointed out in his description of the saints Papias and Stephen, illness in the saints has symbolic value and invokes a certain element of ambivalence in hagiographers; see Crislip, Thorn in the Flesh: Illness and Sanctity in Late Ancient Christianity (Philadelphia: University of Pennsylvania Press, 2013), 17-18. Palladius (another of John's biographers) makes great use of illness in the saints in Laus. Hist. 12.3, 24.2; Crislip highlights Palladius's repeated discomfort with saints who fall ill and draws attention to John's homilies on the topic (Thorn, 182n2o).

47. Pliny rants against the lack of accountability in the profession, which he says is the only one in which killing another human being is permissible and without consequence (Nat. 29.8).

48. See chapter 1 . 
John's presence, as well as his eventual absence, also proves to be spatially transformative. Once again, we return to John's exilic discourse of the Christian experience. This time it is not a universalized vision that moves along with John but an atopia, a nonplace, that reveals the mobility of his orthodoxy:

The blessed Constantine long ago had made that space into a hippodrome before he founded the city. As a result it seems to me that it is owed to that man [John] that all his [Constantine's] works became churches, namely the colonnaded streets [stoai], the agora, the city, the baths, the hippodrome (when the holy father was present, all these places had been filled with prayers, but when he left for exile, they reverted to their previous status), and the church itself, which acquired the additional name and function of an agora. (Ps.-Martyrius, Fun. Orat. 97.7-16, emphasis mine) ${ }^{49}$

What stands out here is that exile, as an identity and as a condition, is a powerful discourse with which to construct oneself outside of a particular space, as Andrade has also emphasized. In this case, John's exile is thought to have brought an end to that vision of heaven on earth, so much so that once John is exiled from the pristine city, the spaces he transformed revert back to what they once were. Like Athanasius's city in the desert, we are left to wonder if it was just a mirage. But this is no Foucauldian reflection; it is a nonplace, an atopia, once the bishop flees.

As John Culbert has assessed, Roland Barthes links atopia, that which is unclassifiable, with the desire for the always-absent other. ${ }^{50}$ The city contains a palpable longing in the absence of the displaced bishop-or, for Ps.-Martyrius, the misplaced bishop. A bishop's absence is as significant as his presence, a claim we saw John make regarding Meletius in the previous chapter. His exile, therefore, becomes a desirable and powerful literary trope. John's legitimacy is preserved in the city. For Ps.-Martyrius, however, it is not the villains that substantiate this claim; it is ultimately the bishop's displacement that confirms John's orthodoxy. ${ }^{51}$ As a victim of persecution, he concludes, we are able to authenticate John's status as a purveyor of truth. Yet John's failure to return remains a significant problem. It takes the return of another story, another fleeing saint, to satisfy the longings of the city, but we must first look to another biographer, whose details of John's victimhood will eventually lead us - and John himself, by way of his biographersback to that golden city.

49. Translation: Andrade, "Processions," 162.

50. John Culbert, Paralyses: Literature, Travel, and Ethnography in French Modernity (Lincoln: University of Nebraska Press, 2010), 34 .

51. Theophilus plays a relatively minor role in this retelling of John's exile. There are many heretics in the text that tempt John and invade his episcopal space. In this particular account, however, Arian maniacs, pagans, barbarians, and even the heretic Origen himself enter the scene in order to substantiate John's power and identity as an orthodox leader. 


\section{HOW TO INTERPRET EXILE: PALLADIUS OF \\ HELENOPOLIS'S DIALOGUE ON THE LIFE \\ OF JOHN CHRYSOSTOM}

Palladius of Helenopolis (ca. 363-420) also constructs a localized vision of John's exile by foregrounding a dystopian image of the cityscape. His Dialogue on the Life of John Chrysostom is meant to rehabilitate John's legitimacy, as well as his own. Palladius appears to have composed his biography during his own exile in southern Egyptian city of Syene..$^{52}$ On the eve of John's second exile, we find not a description of partisan politics but a much bleaker vision of catastrophe and war. The city of Constantinople is invaded by an outsider, and the most unlikely of characters find themselves united: believers, heretics, Jews, and pagans all sympathize with one another over a common cause. The citizens of Constantinople unite and lament the calamity that led to John's expulsion from their most noble city. In that moment of crisis, we find a localized exilic discourse that sheds light on two descriptions of the aftermath of John's expulsion from that beacon of orthodoxy.

Written a year after John's death, Palladius's Dialogue (408) contains four sections: introduction (chaps. 1-4), narration (chaps. 5-11), argumentation (chaps. 12-19), and conclusion (chap. 20). ${ }^{53}$ The text unfolds in the interactive dialogue between a bishop from Constantinople and a deacon in Rome. The narrator, another delegate not unlike those in the introduction to John's letter, travels to defend John's orthodoxy and to clear his name.

Demetrios Katos, building on the work of Florent van Ommeslaeghe, offers a thorough examination of the Dialogue's value as a rich resource for understanding Palladius's involvement in the Johanite crisis. ${ }^{54}$ Many scholars look to Palladius's

52. See Peter Van Nuffelen, "Palladius and the Johannite Schism," Journal of Ecclesiastical History 64 (2013): 28n7. Van Nuffelen challenges the date of Palladius's exile given by both Edward Cuthbert Butler, The Lausiac History of Palladius (Cambridge: Cambridge University Press, 1898), 179-84; and Malingrey, Palladios, 18. Those scholars argue that Theophilus's death marks the turning point in the author's political career and initiates his return to Constantinople. Following the lead of Charles Pietri, Roma Christiana. Recherches sur l'Eglise de Rome, son organisation, sa politique, son idéologie de Miltiade à Sixte III (311440), 2 vols. (Rome: École Francaise, 1976), 1329, Van Nuffelen argues that an amnesty appears to have taken place while Theophilus was still alive and, after John's death and not the death of the Alexandrian bishop. As evidence, he points to passages that present a more tempered Palladius in the Dialogues and political policies that appear to have been put in motion such as those referenced in a letter to Theophilus from Synesius, the bishop of Ptolemais. While I do not agree with Van Nuffelen's reconstruction of a tempered Palladius, he convincingly argues that a major reason why Palladius could return while Theophilus was still alive is that no rivals to the Constantinopolitan see surfaced after John's death.

53. Katos argues that the text should be understood as a legal document that follows the principles of judicial rhetoric traceable to the Art of Political Speech attributed to Aspines of Gadara; see Katos, Palladius of Helenopolis, 46-52. There is an introduction (prooimion), narration (diēgēsis), argumentation (kataskeue), and conclusion (epilogos).

54. Katos, Palladius of Helenopolis. Also see Florent van Ommeslaeghe, "Que vaut le témoignage de Pallade sur le procès de s. Jean Chrysostome?” Analecta Bollandiana 95 (1977): 389-413. Van 
Lausiac History as more historically accurate and by far the most well known of Palladius's works. The Dialogue has also often been viewed either as a history or as a biography but hardly ever as both. Katos convincingly restores the historical value of the text by demonstrating all the traits of judicial rhetoric that make this work a legal defense and help us understand it as a bridge between the biographical and the historical.

The details of John's life, as well as the events that led up to his exile, are carefully crafted in the Dialogue. I depart from Katos's argument that this shift in rhetorical structure eclipses the emphasis upon Origenist controversy in the text. In addition to its use of judicial rhetoric, the text invokes an exilic discourse similar to what we find in Gregory of Nazianzus's panegyric on Athanasius of Alexandria. Like Gregory, Palladius uses episcopal exile to reinstate the authority and orthodoxy of an exiled bishop.

Palladius's introduction includes John's two letters to the bishop of Rome, Innocent I (Ep. 7 and Ep. 41), as well as Innocent's too-little-too-late response. Palladius, himself a traveling bishop, wandering far from the borders of Constantinople, builds on John's account in order to exonerate his hero's reputation. He does this by invoking the theme of justice as one of the basic characteristics of a utopian city. This politeia is balanced and just. All runs afoul, however, once the true and just bishop is removed from the city. Palladius begins:

The unfortunate East has suffered just as in the case of one who has paralyzed limbs realizes that vital forces make their way to the healthier parts of the body. With her limbs entirely paralyzed, the church is unable to function properly, since harmony has abandoned her. Most of us who are her champions and adherents make ourselves exiles from our own country, since we cannot live quietly and safely in our own land, as we love the truth. (Dia. 1, emphasis mine $)^{55}$

Just as John is exiled, so the rest of the church body is quartered and put to flight. As Palladius describes it, the church body is incapable of functioning properly without its bishop there to keep it all together.

Palladius fills in the details and takes great liberties with John's description of his departure from Constantinople. In this extended version of the story, Theophilus is vilified to a greater extent than he is in Ps.-Martyrius's account. Palladius describes him as an irascible character who flies into a tirade at a moment's notice and attempts to undermine anyone who stands in the way of his violent ambitions. He also presents the backstory to John's troubles with Theophilus, which includes a detailed description of his harboring of the Nitrian monks within the walls of city

Ommeslaeghe offers a necessary corrective to an overemphasis on the Origenist controversy as the chief cause of John's exile using source material from the Ps.-Martyrius. This work stems out of van Ommeslaeghe, "De lijkrede."

55. Translation altered slightly. The phrase "make ourselves exiles" is phygades tēs chōras katestēmen. 
of Constantinople. ${ }^{56}$ Their arrival in the city is due in no small part to Theophilus's inability to conduct his ecclesial duties in a just manner. Palladius goes on to shame Theophilus's treatment of the monks in his description of one particularly violent scene:

Certain monks went down to Alexandria with their priests to ask Theophilus to state the reason why they were condemned to be cast out. He regarded them like a dragon with bloodshot eyes. He glared like a bull. With his temper beyond control, he was at first livid, then sallow, and then smiling sarcastically. He snatched the pallium from the aged Ammonius and twisting it around his neck he inflicted blows upon his jaw, making his nose bleed with his clenched fists, and kept crying out: "Anathematize Origen, you heretics!" (Dia. 6)

Heretic or not, Palladius asserts, "one does not treat evil with evil, but evil with good," as a corrective (Dia. 6). The monks subsequently flee Alexandria and eventually make their way to Constantinople for refuge. ${ }^{57}$ Subsequently, John appeals to Theophilus pastorally as a fellow leader of the flock to correct, lovingly and fairly, the wayward.

Theophilus's arrival in Constantinople and his foul treatment of John only further supports Palladius's description of a leader who has lost control. In order to compensate for his failure in his own episcopal see, the madman attempts to cover up his own inadequacies by invading Constantinople. The invading bishop then participates in all manner of sins. He is violent, vengeful, and worst of all, "Theophilus not only spoke as a god, but even imagined he was god” (Palladius, Dia. 7).

John, ever the hospitable leader, welcomes both the wayward monks and Theophilus. If John possesses any fault in this unfortunate tale, it is his generosity for all. His intervention in the controversy ensures his fate as a victim of this insatiable villain's ire. The rest of the section traces Theophilus's endless pursuit to see John come to an untimely end. After he successfully brings about John's first, albeit brief, exile, Theophilus flees back to Alexandria.

After narrating Theophilus's flight, Palladius must momentarily tend to a more pressing issue: John's aiding and abetting of the fleeing monks. In the second section of his narrative, he is forced to contend with the issue of the Nitrian monks in more detail, along with John's controversial relationship with the deaconess Olympias. This section points to the larger controversy circulating in the background of this text. It is not the Arians that trouble Palladius, but those who are invested in the Origenist controversy. John has thus been tied into this later controversy as well, even though it does not take center stage until after his death. Nevertheless,

56. Palladius found himself embroiled in the Origenist controversy due to his friendship and frequent association with some of the biggest fourth-century supporters of Origen (ca. 184-254).

57. Isidore and the Tall Brothers were evicted from the Nitrian desert in 40o. The exiled monks first headed to Palestine but then continued on to Constantinople and arrived by 401 . See Jerome, Ep. 90 (Edition: CSEL 55); and Palladius, Dia. 17. 
as it was for Origen, even death does not place sufficient distance between oneself and the charge of heresy.

Olympias's decision to house and care for the exiled Origenist monks, for example, takes up a great deal of attention. In the first section, Theophilus was already branded as the antagonist and his authority undermined. The deacon listening to the defense, however, is not convinced of John's innocence in relation to the wayward monks. The stench of heresy is too strong to place all the blame on Theophilus, at least until the smell has dissipated. Palladius's inquisitive deacon remarks, "We grant that Theophilus performed a rash action in exiling them [the Tall Brothers], whether they really were orthodox or heretical. At any rate, the deaconess should not have taken them in" (Dia. 16). It is undoubtedly troubling, we are to assume, that a deaconess housed monks who were exiled by a bishop, even if that bishop's authority is questionable at best. Her involvement in the scandal must therefore be dealt with, especially since Olympias is the known benefactress of John. In addition to John, Olympias (and all of John's supporters) must also be cleared of all charges of heresy. Palladius justifies her actions by stating that the sympathy she showed the monks is a testament to her Christlike commitment to charity. He reminds his readers that Jesus fed a mixture of good and evil persons among the three thousand and that he ate and drank with both publicans and sinners. Olympias, like John, is guilty of nothing more than extreme, albeit naive, generosity. Once Palladius has cleared the air, he turns once again to the cityscape in order to restore John's name and reputation.

The final section of Palladius's Dialogue darkens as the entire eastern empire quickly deteriorates into a landscape of lawlessness. Stories of suffering overrun this section of the work and leave the reader with a sense of desperation and hopelessness. To solidify his argument, Palladius begins by taking stock of all those bishops who were sent into exile along with John: "I am referring to Eulysius and Palladius and Cyriacus and Demetrius. We have heard by the grapevine that they were banished" (Dia. 19). Their fate, much like John's, is to suffer for their orthodoxy. Their suffering is the very proof of their innocence, but the picture grows dim as the battle between good and evil wages on and they are thrown into further chaos: "As for the bishops, a first rumor had it that they had been drowned in the sea. However, the true story is that they were banished beyond the borders of their own territory into barbarian zones, where they are even now still kept prisoners and under police guard" (Dia. 20). Palladius then provides a lengthy list of the whereabouts of and the inflictions suffered by each of the exiled bishops scattered across the empire. For example, "Serapian ... underwent bodily tortures at the savage treatment from his judges, even to the extraction of his teeth. ... Hilarius, an aged holy man, was transported to innermost Pontus after he was beaten up, not by the judge mind you, but by the clergy. . . . Heracleides of Ephesus has been shut up in the prison of Nicomedia for four years now" 
(Dia. 20, emphasis mine). ${ }^{58}$ As Palladius highlights here, the enemies of the faithful are not the enemies of old, although they too take pleasure in inflicting harm. These enemies are the false clergy, who are to blame for the most horrendous acts of violence. Palladius points to the treatment of the blessed Eutropius to stress his point: "undefiled of women, a cantor, was struck and flayed most unmercifully on his sides and forehead so that his eyebrows were pulled out. Finally oil lamps were lit close to his ribs, which had been laid bare to the bone on both sides, and he expired on the rack. He was buried in the middle of the night by the clergy who had committed this crime" (Dia. 20, emphasis mine). Palladius uses what should now be a familiar theme: exilic discourses continuously invoke a past of persecution in order to substantiate authentic orthodox Christian identity. The imperial thugs are no longer the instigators of imperial persecution; it is now the false clergy who eagerly partake in these nefarious activities. This past, Palladius stresses, does not disappear with the arrival of so-called Christian emperors or with the surfeit of professed Christians in the church. Instead, we are to conclude that the mixing between empire and heretics is the ultimate cause of this particular dystopian nightmare. The picture is indeed bleak. Palladius then provides proof text after proof text that the end times, which were inaugurated with John's exile, have arrived. ${ }^{59}$

John's orthodox flight is the ultimate testament of truth. His banishment and subsequent suffering give hope to others who suffer the same fate and provide yet more people with an excellent example of someone who had no earthly claims. His suffering was his bodily condition in this world. Even before John was exiled, Palladius states, he held this life at a distance. His focus was on performing good works, not amassing wealth or human prestige. His suffering would therefore be beneficial to all who continue to read about his life: "He did not make a will in regard to his property, since he had already disposed of all by his life and thinking. Did death knock at the door of his emaciated body? Before John beheld him outside, he shouted: 'Let us go from here', and he intoned the Psalm: 'Woe is me that my sojourn has been so long'" (Dia. 20). Palladius then contrasts this exemplary man with those who claim to be orthodox but are instead false Christians, who also flee, but flee as cowards. He then turns back to Theophilus:

His nights are sleepless and troubled. He imagines plots against himself even by his associates. He has lost faith in himself and distrusts all men as liars. This is what he resembles: he is as cowardly as a rabbit, as bold as a swine, as deceitful as a chameleon, as roguish as a partridge, as pitiless as a wolf, and as untamable as a mouse. He is his own enemy, jealous without cease, punishing himself though he reckons it not. One who continually plots evil for others inevitably brings it on himself. (Dia. 20)

58. The phrase "not by the judge ... but by the clergy" is ou dikastou, alla tou klèrou. 59. 1 John 2:19; 2 Thess 2:3; John 2:18; Matt 20:1, 6. 
While Theophilus harbors safely in Alexandria, the faithful continue to live with this ongoing nightmare and are forced to flee in every direction. Nevertheless, Theophilus points to an eventual resolution. Palladius closes his dialogue by reasserting that John's exile will not go unrectified, even though, at present, it causes insurmountable suffering. The faithful now live within a nightmare, but justice will come: "For even though the blessed John has gone to sleep, nevertheless, truth is very much awake, for which a search will be made" (Dia. 20). The final judgment has yet to come, Palladius insists: "The divine justice will hunt them down to correct their evil actions" (Dia. 20). Peace will be restored and the church of Constantinople will once again be a heavenly city.

John's vision of a utopian Constantinople comes under threat with the invasion of a competing urban space. In his Epistle 7, Constantinople's position as a preserved city of orthodoxy quickly crumbles, as John's troubles escalate and he is exiled. His quick tongue, hot temper, and reforming practices, according to both his ancient and his contemporary biographers, make it easy to see why such a divisive figure found himself deposed from his position. John's own interpretation of the events that eventually lead to his exile, edited and reframed by Palladius, creates a powerful exilic discourse about the rivalry at play between Alexandria and Constantinople. This urban defender of Nicene orthodoxy comes to blows first in John's exilic discourse. And once Palladius enters into the Origenist controversy, the spatial imagination defines the terms of his orthodox project through a dystopian vision of crumbling landscapes and displaced men.

HOW TO RETURN FROM EXILE: ATHANASIUS

AND JOHN CHRYSOSTOM

We have seen that the difficulty in writing the history of John's exile is generated by the consistent conflation of various representations of his exile. By focusing instead on the use of space and place in each text independently, we now discover new ways to examine John's exile. I have drawn to the fore how the different investments of each author shape each text. As we saw in John's apologetic treatises, in the last chapter, he characterizes his exile as a universal condition. The exilic condition is not defined by any earthly homeland but by a heavenly politeia. Here we see a similarity to Athanasius's exilic discourse, which transforms into an embodied orthodoxy that is bound neither by space nor, in Antony's case, by time. But this universalized exilic discourse is not what survives. As Palladius and Ps.-Martyrius demonstrate, the orthodox process is dependent upon John's exilic discourse localized in the city and an eventual return. These biographies show us most clearly how displacement secures John's identity as an exile. But is this enough to ensure his orthodoxy? Ultimately, John's memory is successfully resurrected, but only with the help of a victorious Alexandrian legacy-not that of Theophilus, but of Athanasius. 
We might now understand why the intersection of exilic discourse with the discourse of orthodoxy and heresy is so productive in the afterlives of these exiled bishops. The exiled person, while fragile in his displacement during his own time and exile, embodies an orthodoxy that can be used and (re)placed by his biographers. The exiled bishop lives on as a moveable object. His narrative is constructed through literary tropes in order to promote and sustain definitive borders of what is considered and will eventually constitute a pro-Nicene orthodoxy that is unquestioned. We will explore this argument in the next chapter. For now, let us turn back to Athanasius and his refashioning of his second exile to see how John's biographers connect their hero to this emblem of orthodoxy.

In the summer of 339, Athanasius composed his Encyclical Letter while safely harbored in Rome, in which he constructs an identity as both victim and victor. ${ }^{60}$ The contents of the letter describe for his audience the series of dramatic events that resulted in what is considered his second exile. ${ }^{61}$ It is in this encyclical that Athanasius first constructs himself as a persecuted victim, while simultaneously stylizing himself as an unconventional literary hero. He accomplishes this through several steps. In his effort to create an unstoppable protagonist, Athanasius creates the most threatening of enemies: Gregory of Cappadocia. He then describes a particularly violent scene that had devastating effects on the faithful. Finally, he argues that his eventual flight was necessary for the benefit of the Alexandrian community and the church at large.

Athanasius begins his letter by emphasizing that Gregory is no ordinary villain. He is a foreigner with a particular taste for blood and a penchant for keeping bad company. Gregory and his associates are all "Arian madmen" (Ep. encycl. 2). ${ }^{62}$ To drive home the dubious nature of these intruders, he makes it clear that these men were, in fact, those responsible for his first departure to Trier. He then turns to a climactic moment that condemns his enemy further. Gregory's bloodlust is not for Athanasius alone but extends to the entire city of Alexandria. In the days preceding Athanasius's flight to Rome, Gregory gathered his Arian madmen and other co-conspirators, such as a known Manichean general, along with his disreputable imperial soldiers, to storm the "Great Alexandrian Church" (Ep. encycl. 7). ${ }^{63}$ Calamity ensues, and Athanasius describes the disaster as follows:

The church and the holy baptistery were set on fire, and straightway groans, shrieks, and lamentations were heard through the city; while the citizens, in their indignation

6o. Athanasius, Ep. encycl. Edition: Opitz, Athanasius Werke 2, 169-77.

61. Barnes, Athanasius and Constantius, 50.

62. For a detailed discussion on the rhetorical degradation and creation of the category of Arian madmen in Athanasius's other works, see Burrus, Begotten, Not Made, 47-68.

63. According to Barnes, the "Great Alexandrian Church" to which Athanasius refers here is the Church of Dionysius mentioned also by Socrates, Eccl. Hist. 2.11, 6, and Julius, Ep. 1 (341); see Barnes, Athanasius and Constantius, 49. 
at these enormities, cried shame upon the governor and protested the violence used against them. For holy and undefiled virgins were being stripped naked, and suffering treatment that is not to be named, and if they resisted, they were in danger of their lives. (Ep. encycl. 3)

Here I want to point out two details: First, the chosen location of this attack is the very heart of the Christian church: the baptistery. Second, virgins, presumably sexually assaulted in this scene, are highlighted as the chief victims of this attack. Gregory's violence is highlighted as both excessive and intentional. He targets the most vulnerable within the community. What is also striking about this passage, aside from the horrific events described, is the way this storyline develops over the course of Athanasius's career as an exile. This event is detailed along with the atrocities enacted by Gregory's successor, George, in both his Defense before Constantius and In Defense of His Flight. ${ }^{64}$ These attacks upon Athanasius and the vulnerable continue to take place as if the imperial persecutions were still alive and well. ${ }^{65}$ The only difference in this new martyrdom is that the bishop flees in order to stay alive.

Athanasius's survival does not go without criticism, however, and he must answer to the charge of cowardice in his Defense of His Flight. In this text, Athanasius concludes that it is more cowardly to persecute the innocent (i.e., the virgins and the elderly), while it is manly and Christlike to flee (Fug. 2.1). In short, this bishop is more valuable alive than dead.

Athanasius outlived his enemies and eventually returned to Alexandria triumphant. As we saw in chapter 2, his story takes on mythic proportions as it travels across the empire. Gregory of Nazianzus, in his panegyric delivered in Constantinople on the anniversary of Athanasius's death, never questions Athanasius's decision to flee. And to legitimize his hero's flight, Gregory goes so far as to describe Athanasius's exiles as an "illustrious banishment" and not an exile (Orat. 21.27). This point is proven by his successful return to Alexandria, which is the focal point of his speech. As Gregory narrates it, Athanasius enters the city with accolades and cries of victory over the Arian enemy.

Athanasius's legacy as a persecuted victim is thus intimately tied to graphic stories of violence and suffering, such as the invasion of the Alexandrian church and baptistery. Athanasius's survival is nothing short of miraculous and certainly lives on as a story of legends. ${ }^{66}$ With each retelling, this story of triumph became

64. Athanasius, Apol. Const. 27, and Fug. 6.24. The texts are discussed in chapter 1.

65. Julia Hillner, Prison, Punishment, and Penance in Late Antiquity (Cambridge: Cambridge University Press, 2015), 249-55.

66. Athanasius's repeated escape does not go without criticism. In the Defense of His Flight, Athanasius must address the charge of cowardice. Ultimately, he'll conclude that the death of martyrs, while valuable, is not the only example set by Christ. The command to flee during times of persecution in 
intertwined with the victory of Nicene orthodoxy and, therefore, the victory of the saint. Athanasius's story continued to take on cultural capital across the empire as Nicene Christianity built momentum, particularly in Constantinople. As the so-called defender of the faith, the Alexandrian bishop's reputation was used to substantiate other claims to orthodoxy and to rehabilitate, even posthumously, those like John Chrysostom who suffered from the suspicion of heresy. Unlike Athanasius, however, John did not have a victorious return, at least not while he was alive.

Both Ps.-Martyrius and Palladius successfully transform this questionable exile into a saint through the aid and agency of Athanasius. They accomplish this task by drawing strong narrative connections to the Nicene hero's struggles with invading bishops. The violence inflicted upon John's supporters and subsequent damage to the Constantinopolitan church also mirrors those events described in Athanasius's Encyclical Letter. Finally, John's biographers explicitly refer to Athanasius as a way to legitimize John's orthodoxy and transfer the Alexandrian legacy to Constantinople.

The literary connections begin when we compare invading episcopal competitors. Theophilus, for example, was a conniving politician whose lust for power extended well beyond the borders of his episcopal see. He leaves Alexandria and travels to Constantinople in order to convoke the Synod of the Oak and condemn John. Although John was never present at the synod, his absence ensured a guilty verdict. As Elm has noted, no clear doctrinal issues appear to be at stake between the two men, or at least no overt charge of heresy was made at the synod. John was never labeled an Origenist, for example. One does not have to be called an Arian or an Origenist, however, to be implicated by the company one keeps. Heresy by way of association is enough to discredit one's opponent, as we have seen time and again.

Guilt by association goes both ways. John's two biographers are fully aware of such rhetorical strategies and thus make use Athanasius's story to clear John of any wrongdoing, heretical or otherwise. Both Johanite apologists go further to turn the charge on its head and accuse Theophilus, not John, of keeping bad company. In both texts, Theophilus stands as John's literary foil and functions in a similar way to Athanasius's chief rivals. Theophilus's role as an invading bishop who colludes with other known heretics, criminals, and imperial officials bent on persecuting the orthodox was not lost on John's supporters. This is a story we have heard before. The actions of this invading bishop actively undermine his claim to the power of the Alexandrian episcopate or, at the very least, his orthodox legacy. That authority shifts to a new context and a new bishop. As we will come to see,

Matthew 10:23 is frequently cited by Athanasius and other fleeing bishops ("If they persecute you in this city, flee into another") (Athanasius, Ep. encycl. 5). 
Constantinople and John Chrysostom are the true inheritors of the Athanasian legacy. The city envelops Alexandria as Athanasius's story is first carried in and then reread within its walls.

The narrative sequence of violence explored in Athanasius's encyclical is inserted into both Ps.-Martyrius's and Palladius's accounts. In the Funerary Speech we see:

When some of those who come to the holy rites of initiation had just emerged from the pool of the baptismal font, others were still in it, and others were ready to immerse themselves, [when] a solid mass of soldiers entered with swords and clubs.... They beat and drove out those who lacked both clothing and sin, ... sparing no one, not even women, whose natures have taught especially to feel shame at being naked [Gen 3:7-11]. (Ps.-Martyrius, Fun. Orat. 93)

Once again, it is the baptistery that is invaded and, in their mad pursuit of John, these enemies target the faithful, even persons in the very process of Christian initiation.

We see an extended version of this same event in Palladius's text. Like Ps.-Martyrius, the attack on the church takes place at the Easter Vigil. A vicious soldier named Lucius the Greek brings with him known clerics of John's rival and enlists swordsmen to storm the inner sanctuary of the church. ${ }^{67}$

At night, he suddenly rushed to attack, furious, like a wolf, along with the priest who showed him and his soldiers the way. He pushed through the crowd with a sword, he came forward to the holy waters and cast out those who were about to be initiated into the Resurrection of the Savior. He arrogantly pushed aside the deacon and spilled the symbols of the mysteries. As for the priests, who were of a certain age, he struck their skulls with a club and defiled the baptismal pool with their blood. ... Naked women with their husbands were running away wounded, disgracing themselves for fear of being killed or disgraced. (Dia. 9.196-205)

In both narratives, John's enemies invade the baptistery, treat the initiates violently, and lay out the naked bodies of women before us. It is as if Gregory's attack has taken place once again, only this time in Constantinople. The faithful are tortured and, as we might expect, the bishop is expelled.

If the familiar narrative structure were not enough to link Athanasius to John, both authors explicitly refer to "the Great Athanasius of Alexandria" when they discuss the aftermath of John's first exile and presumably illegal return to Constantinople. Each author reports that, after the legitimacy of the Synod of the Oak was called into question, Theophilus fled back to Egypt and John was recalled from exile. The emperor Arcadius demanded an explanation, and Theophilus was also requested to return. He refused to do so and sent representatives instead. Theophilus's delegates did not come empty handed but carried with them the same canons that were meant to discredit and condemn Athanasius. In Ps.-Martyrius's account,

67. This character parallels Philagrius, the prefect of Egypt and noted kinsman of Gregory in Athanasius's story; see Athanasius, Apol. sec. 5.4, and H. Ar. 10.1. 
we read: "Having thoroughly investigated every form of slander and wickedness and having discovered that all <their efforts $>$ were being overcome by the truth, they sought refuge in the illegal laws of the Arians and with them plotted evil concerning the saint [John], copying < the Arians'> madness concerning the blessed Athanasius" (Ps.-Martyrius, Fun. Orat. 98). Athanasius's supposed illegal return to his episcopate is invoked to parallel that of John's experience. Ps.-Martyrius describes the contents of the letters as follows:

But being worsted in everything by the man's [Athanasius's] freedom of speech and by the true course of events, they finally deposed him on the grounds that he was a father of heresy and falsified the teaching of the apostles. However, suspecting a change in the political situation, they added to the deposition <of Athanasius $>$ a law that laid down that it was in no way whatever permissible for a deposed person to have his case adjudicated a second time. (Fun. Orat. 99)

Ps.-Martyrius seeks once again to overlay John's story with that of Athanasius. Like Athanasius, John's fatal flaw appears to have been his daring decision to return. Despite the accusations of heresy and general misconduct, these two bishops defied the stipulations of their depositions. According to Ps.-Martyrius, Athanasius's enemies, knowing that the charge of heresy would not stand (just as John's would not), added an additional clause stating that a second trial could not take place after a bishop had been deposed. John, even after an unnamed countercouncil cleared him of all charges of heresy, violated this added precautionary measure.

Palladius also refers to these same documents. The story repeats: After John returns from his first exile, Theophilus sends delegates with "certain canons, which the Arians had composed against the blessed Athanasius" (Dia. 9.19-20). These laws are ultimately deemed false by Palladius, given their dubious origins, but nevertheless cause him pause. He must explain why John does not violate any canons, legal or illegal. First he states, “They [John's enemies] thought that by the use of these canons they could devise a judgment against John, because he had returned to his see after being deposed-and that was on his own initiative" (Dia. 9.19-20). ${ }^{68}$ Palladius later details the contents of the canons in question: "The forty bishops who held communion with Arius had legislated that if any bishop or any priest who had been deposed, justly or unjustly, should reenter his church on his own initiative, without permission of a synod, such a one shall have no opportunity of defense, but shall be absolutely excluded.' Now that

68. Barnes and Bevan note that the canons appear to be from an Antiochene council c. 327; see Barnes and Bevan, Funerary Speech, 216n95. The reaffirmation of these canons is then linked to the Council of Antioch in 341; see Palladius, Dia. 9.60-63. The canon reads, "if a bishop deposed by a council ... attempts to perform any liturgy, ... it should no longer be possible for him to have a hope of being restored or the opportunity of defending himself, not even at another council." Edition: Joannou, CSP, 1962b, 107. 
canon was found to be lawless and passed by lawless persons" (Dia. 9.62-65). Palladius goes on to explain that these canons, presented to the emperor Arcadius, caused a great deal of confusion. Some agreed they were illegal, while others deemed them orthodox.

Palladius notably makes no mention of a countercouncil that cleared John of his charges. Instead, he dismisses the Synod of the Oak as an illegal civil tribunal and states that John's first removal was not, in fact, a legal deposition. John's initial return, then, did not violate any canon law, no matter its origins. This statement, of course, undermines Ps.-Martyrius's narrative, which may have more to do with Palladius's own precarious position as an exile and attempt to return than with John's activity.

Ps.-Martyrius and Palladius do agree, however, that the attempts to use these canons by John's enemies forge a strong link between John and Athanasius. It is John, not Theophilus, who is the rightful heir of Athanasius's legacy. The narrative of John's persecution and expulsion mirrors that of Athanasius's account discussed in the encyclical. Moreover, the canons carried by Theophilus's delegates reflect the charges of heresy and misconduct back upon John's accusers. It is the company Theophilus keeps, not John's associates, that condemn this invading bishop.

\section{CONCLUSION}

The Athanasian legacy was so successful that, by the time John Chrysostom's seemingly failed exile took place, the simple act of invoking Athanasius's experience was enough to resurrect and rehabilitate John's memory. Athanasius's larger-than-life persona as an exile was carefully constructed both in his own writings and in those of his supporters. His many exiles served as a powerful narrative and identity that was recycled across the empire. While stories of Christian orthodoxy were still intimately tied to the not-too-distant past of imperial persecution, claims to Christian authority were derived not from the dead but from the living. Unlike the heroic martyrs before him, however, Athanasius was not simply a victim. His legitimacy was confirmed by his ability both to suffer and to defend. He survived so others might live. John Chrysostom, like Athanasius of Alexandria, was brought back to the city and triumphantly proclaimed a defender of the faith precisely because his exile mirrored that of his literary and orthodox predecessor.

We began to see in this chapter how the Athanasian legacy and its role in preserving or challenging orthodox identities functioned in and around Constantinople. That legacy frames our understanding of John Chrysostom's political and theological troubles as the reigning bishop of that contested city. As we saw in chapter 3, certain alliances with Antioch continued to cause trouble for those men who attempted to hold on to the episcopal office in Constantinople. It is not 
surprising that John's support of Meletius of Antioch and his connections with his successor, Flavian, did not endear him to the Alexandrian patriarchate and, by extension, the pro-Athanasian legacy. Yet, in hindsight, John Chrysostom has still been remembered as an unquestionably orthodox figure. And we now begin to see how John's biographers played a key role in reviving not just John's reputation but Athanasius's as well. The Alexandrian legacy as a pro-Nicene position must be moved to Constantinople and embodied in stories of its heroes. At least, this is the claim the ecclesiastical historians would make, to which we will turn in the final chapters. As they, too, sift through and (re)place the bodies of bishops in flight, they will reset the stage of the pro-Nicene narrative and reinforce one of the primary arguments of this book: the space and place of orthodoxy is central to our understanding Christian flight in late antiquity. 